\title{
Editorial
}

\section{Music education and global fiscal questions}

Music education is a worldwide activity. Gatherings and conferences where music educators from around the globe meet together are always interesting arenas, with as many discussions going on in the various watering holes near the conference venue as take place in the sessions themselves. But what we actually mean by music education often becomes an absorbing topic in its own right, and one we have discussed previously in these editorials (inter alia Fautley \& Murphy, 2015). Differences are not just about matters of delivery, however; they also reflect often complicated local contexts and histories. They are at once philosophical, concerned with policy, concerned with curriculum, with progression, with assessment, with delivery, with modality, with jurisdictional requirements, and with regulations. All this makes for an interesting subject base.

One of the many strands of thinking in global music education at the moment concerns the nature of what it is that music education - in whatever local form it takes - is trying to achieve. In other words what is musical thinking and what is a musical activity? We talk about something being musical or unmusical, about a performance having quality, about a composition being moving, but what do we mean by these words? And what, given that we are music educators, can we actually do about them? We obviously want our learners to develop some form of musicality, but what does that mean? This becomes really problematic for us in the age of austerity in which we are now living, when our political paymasters ask us not just, 'what does it mean to be musical?' but also, 'how much does it cost to make someone musical?' These are both difficult and contentious questions. Of course, it is easy enough to shrug our shoulders and say that music is an art, and you can not put a price on it, but the real and present danger with doing this is that politicians will simply tell us that if we cannot do that, then they'll give all the money they were going to give us to STEM subjects instead!

But how quantitative can we become? We have Gladwell's (2008) albeit contested notion that it takes 10,000 hours of practice to become expert in something (he includes aspects of music in this). Do we simply take that number, put an hourly rate on it, and tell our politicians that is what it will cost? This seems unlikely to help our cause - and will be very expensive. So what can we do? One thing we may need to do more of is to understand the nature and form of what we are doing, whatever it is, and wherever we are doing it. This is one of the virtues of academic journals, in which society the British Journal of Music Education is proud to be a member. We need to understand more, and to understand more we need to know more, hence there is both a want and a need for more research in music education.

This means that knowing about, and understanding, the perspectives and stances of other views of music education becomes all the more important. Even within our own cultural enclaves there can often be profound disagreements about what is, and what should be, going on. In these times of austerity, if we are not careful, we will face the very 
real risk of so busily arguing amongst ourselves that we do not see the potential approaching danger we may all be cut out of existence at the whim of a spreadsheet operator.

But enough doom and gloom. Let us celebrate the wide diversity and range of knowledge which BJME encompasses, and look, and learn, from the research we present in this issue from around the world. We begin with an article from the UK, where Hallam and Rogers investigate the impact of instrumental music learning on attainment at age 16. There is a lot of talk internationally about the transferability of music learning, and, as we discussed above, this is a key matter for researchers, educators and policy makers. This article shows that, viewed from a UK perspective, there is a correlation between playing a musical instrument and performance in national examinations. This is useful and important - for us to know. From here we move to Finland, where Muhonen considers primary school learners' experiences of songcrafting, especially the role that this plays in developing creative agency. Creativity is a frequently heard $21^{\text {st }}$-century buzzword, and we need to ensure we keep music at the heart of such discussions. From Finland we move across to the other side of the world, and visit New Zealand, where Wise discusses secondary school teachers' approaches to teaching composition using digital technology. Creativity is again central here, but Wise reports that teacher use of technologies for composing often tends to be traditional and procedural in nature. Some issues here for the Global community to consider, surely?

We move back around the globe again for our next piece, which comes from Sweden, where Bjerstedt presents a study of improvisation in jazz musicians, and investigates how jazz students learn to improvise. Here Bjerstedt calls for a multivariety of didactic loci, and asks some pertinent questions for us all to consider in our various pedagogic practices. We head East next, to Singapore, where Costes-Onishi invites us to think about the intersections between formal and informal learning. Again, we hear a lot about formal and informal learning in music, so here it is really interesting to be thinking about them in the context of at-risk students. Finally our circumnavigation of the world brings us back to where we began, and the UK, where Pitts and Robinson describe the experiences of sustaining and ceasing amateur participation in classical music. Again, they invite us to consider difficult questions in music education: here the place of involvement in musical participation after full-time ceases.

The pages of this edition of the $B J M E$, as is so often the case, take us to many different countries, and different traditions in music education, yet, as we observed in the opening of this editorial, all of this information is both useful and informative, and helps us in our thinking about, and understanding of, the complex world in which we live.

MARTIN FAUTLEY and REGINA MURPHY

BJME Co-Editors

\section{References}

FAUTLEY, M. \& MURPHY, R. (2015) Editorial: What is music education? British Journal of Music Education, 32(1), 1-4.

GLADWELL, M. (2008) Outliers: The Story of Success. New York: Little, Brown and Co. 